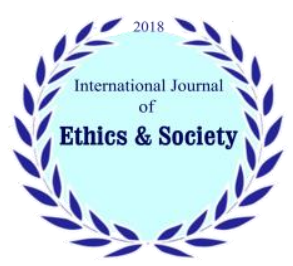

International Journal of Ethics \& Society (IJES)

Journal homepage: $\underline{\text { www.ijethics.com }}$

Vol. 3, No. 3 (2021)

(Original article)

\title{
Designing an Ethical Targeted Marketing Model by Identifying Factors Affecting Customer Clustering
}

\author{
Hossein Barati Teimouri, Jalil Gharibi *, Ali Hosseinzadeh, Alireza Pooya \\ Dept. of Management, Torbat-e-Heydarie Branch, Islamic Azad University, Torbat-e-Heydarie, Iran.
}

\begin{abstract}
Background: The purpose of this study is to investigate the role of customer clustering in the design of an ethical and targeted marketing model in Internet of Things (IOT) Technology Services Companies.

Method: The research method is applied, exploratory and mixed (qualitative-quantitative). Qualitative section: 15 people of sales and marketing managers of IOT companies, were selected for in-depth interviews by targeted and snowballs methods. In this phase used entropy and VIKOR decision-making techniques. The software used in this phase was Max QDE. Quantitative section: In this phase, all the customers of the studied companies were included, and due to the unlimited nature of the society with Morgan's table, 384 people were selected as the sample size by non-random and available methods. The data collection tool in this section was questionnaire, which used Cronbach's alpha to examine the validity of the questionnaire. In order to analyze the data, the exploratory factor analysis method and Partial least squares structural equation modeling (PLS-SEM) with Smart-PLS2 and Liserl software were used.

Results: Qualitative section: In this phase, four clusters were identified: communication factors, ethical and behavioral factors, individual factors and economic factors

Quantitative section: In this phase, the model obtained in the first phase was quantitatively examined and validated and approved.

Conclusion: The results showed that four main clusters: communication factors, ethical and behavioral factors, individual factors and economic factors are dimensions of targeted marketing and customers are classified according to their characteristics. So, these companies should pay attention to these items as methods for sales promotion.
\end{abstract}

Keywords: Ethical targeted marketing, Entropy, VIKOR, Customer clustering, Internet of things.

* Corresponding Author: Email: jgharibi2017@gmail.com

Received: 03 Apr 2021

Accepted: 03 May 2021 


\section{Introduction}

Today, companies use marketing to attract customers, marketing must be ethical and purposeful, so by identifying the demands of customers and get their satisfaction and trust, they will become loyal customers. One of the ways to achieve ethical and targeted marketing is to use customer clustering. Many organizations today find that customer databases are an important asset they have. Analysis of these databases through data mining and targeted customer clustering is one of the most important needs of Sales and marketing units (1). The benefits of data mining and its applications in the industry are increasing every day; because it helps business owners identify hidden information under a huge amount of data and this will allow these industries to better understand their customers in the marketplace (2). In this context, data mining has a variety of tools, one of the most important of which is cluster analysis. Some of the most widely used data mining techniques in marketing are different clustering techniques. These techniques are perfect for market segmentation and compared to traditional and intuitive methods of market segmentation and they can also help marketers to improve their performance more effectively (3).

Activities such as long-term planning and marketing should be planned and executed purposefully with adequate input from different client segments and their clustering and classification, so that the organization can be as productive as possible (4). Considering that in today's dynamic world, the corporate climate has changed from product-centric to consumer-centric, recognizing customer ethical behavior has become more relevant, and one of the most critical tasks for customer-centric companies is to identify and appreciate customers ' preferences (5). In fact, the study of consumer ethical behavior is a way for companies to better understand the market and identify new prospects for growth (6). Furthermore, most companies have realized that the customer database is one of their most valuable tools and most of them use this database by evaluating the consumer information in order to establish marketing strategies (7).

62

Available at: www.ijethics.com
Research shows that in recent years, multi-criteria decision-making methods have been one of the most effective strategies for assessing and selecting the most appropriate factors and alternatives (8). Among the decision-making methods, the entropy technique is one of the most important methods for measuring the weight and importance of indicators (9). Additionally, many decision-making strategies were introduced to rate and pick the most appropriate alternatives and the VIKOR method is one of the most important methods in this category. Thanks to the fact that a range of choices can be identified as accepted responses in this method, so this approach has been used to identify and evaluate categories of customers (10).

In recent years, technologies have played an important role in improving the business environment and making it more competitive which Apart from having influence on industries, this has contributed to the emergence of technology-based companies that operate on the basis of information technology and IOT service providers are one of those businesses. On the other hand, owing to the infancy of these companies, little work has been done in this area which means that there are multiple areas for study and research in "IOT Service Providers" and Customer clustering is one of those areas.

This issue was not addressed in previous researches, and was ignored and in the present paper, given that these companies are trying to obtain more customers for growth and advancement through different methods such as clustering, therefore a combined method using entropy and VIKOR technology was then used to analyze consumers and customer clustering of Internet of Things products, which was done to select the appropriate marketing technique.

\section{Material \& Methods}

The research method is applied, exploratory and mixed (qualitative-quantitative).

Qualitative section: 15 people of sales and marketing managers of IOT companies, were selected for in-depth interviews by targeted and snowballs 
methods. In this phase used entropy and VIKOR decision-making techniques. The software used in this phase was MAXQDE.

Quantitative section: In this phase, all the customers of the studied companies were included, and due to the unlimited nature of the society with Morgan's table, 384 people were selected as the sample size by non-random and available methods. Data collection tools were used in the qualitative section of the interview and in the quantitative part of the closed questionnaire, which covers all aspects of the sample influenced by the identification of customer clusters, with a 5-point Likert scale (I totally agree $=5$, I agree $=4$, I have no opinion $=3$, I disagree $=2$ and I absolutely disagree $=1$ ) Variables were measured. Cronbach's alpha was used to evaluate the validity of the marketing and reliability experts' questionnaire, which was 0.86 and confirmed. In order to analyze the data, the exploratory factor analysis method and Partial least squares structural equation modeling (PLS-SEM) with Smart-PLS2 and Liserl software were used.

\section{Results}

Qualitative section: First, the demographic findings of the sales and marketing managers of companies providing Internet of Things technology services were examined, and the results showed that 6 of them were female and 9 were male, 2 had a bachelor's degree, 7 had a master's degree, and 6 had a doctorate. Also, 1 of them was between 20 and 30 years old, 5 people between 30 and 40 years old and 9 people over 40 years old, which shows that most of the sales and marketing managers of companies are men and people with master's degree and over 40 years old.

A review of the literature led us to the initial clustering for customers according to Table 1. Sub-factors are identified in Table 1.

Table 1: Factors and initial customer clustering

\begin{tabular}{|c|c|c|c|c|c|}
\hline Factors & $A_{1}:$ Customer Loyalty & $\begin{array}{c}A_{2}: \text { Communication } \\
\text { factors }\end{array}$ & $\begin{array}{c}A_{3}: \text { Customer relation } \\
\text { management }\end{array}$ & $\begin{array}{l}A_{4}: \text { Ethical behav- } \\
\quad \text { ioral factors }\end{array}$ & $\begin{aligned} A_{5}: \text { Customer sat- } & \text { isfaction }\end{aligned}$ \\
\hline $\begin{array}{c}\text { Sub } \\
\text { Factors }\end{array}$ & $\begin{array}{l}\text { Easy access to the product } \\
\text { Meet customer expecta- } \\
\text { tions } \\
\text { customer services } \\
\text { Appreciate the customer } \\
\text { Reputation } \\
\text { Develop customer rela- } \\
\text { tionships } \\
\text { Special offers } \\
\text { Giving the customer a } \\
\text { chance to make decisions } \\
\text { Considering market condi- } \\
\text { tions } \\
\text { Pay attention to statistics, } \\
\text { figures and research results }\end{array}$ & $\begin{array}{l}\text { Service usage } \\
\text { Revisit rate } \\
\text { The extent of communi- } \\
\text { cation with the company } \\
\text { Suggestions } \\
\text { Shopping rate }\end{array}$ & $\begin{array}{l}\text { Service and communica- } \\
\text { tion channels } \\
\text { Supportive technologies } \\
\text { Employee knowledge } \\
\text { and awareness } \\
\text { Organizational commu- } \\
\text { nication and culture } \\
\text { Customer management } \\
\text { process }\end{array}$ & $\begin{array}{l}\text { Quality } \\
\text { Recommend others } \\
\text { Service functions } \\
\text { Shopping experi- } \\
\text { ence } \\
\text { Advertising } \\
\text { Service support }\end{array}$ & $\begin{array}{l}\text { Compliance with } \\
\text { expectations } \\
\text { Variety of prod- } \\
\text { ucts } \\
\text { Ease of purchase } \\
\text { after sales services }\end{array}$ \\
\hline Factors & $A_{6}:$ Economic Factors & $\begin{array}{c}A_{7}: \text { Factors affecting the } \\
\text { non-purchase of cus- } \\
\text { tomers }\end{array}$ & $\begin{array}{c}A_{\mathbf{8}}: \text { Customer experi- } \\
\text { ence management }\end{array}$ & $\begin{array}{c}A_{9}: \text { Individual fac- } \\
\text { tors }\end{array}$ & \\
\hline $\begin{array}{l}\text { Sub } \\
\text { Factors }\end{array}$ & $\begin{array}{l}\text { Service prices } \\
\text { Income level } \\
\text { Job } \\
\text { Sales discounts } \\
\text { selling the credit } \\
\text { leasing }\end{array}$ & $\begin{array}{l}\text { Foot } \\
\text { Shift } \\
\text { New communications } \\
\text { Better choice or alterna- } \\
\text { tive goods } \\
\text { Dissatisfaction with } \\
\text { product quality } \\
\text { Improper behavior }\end{array}$ & $\begin{array}{l}\text { Associated with adver- } \\
\text { tising } \\
\text { solve problems } \\
\text { Promise Brand } \\
\text { Support }\end{array}$ & $\begin{array}{l}\text { Age } \\
\text { Gender } \\
\text { Level of education } \\
\text { Modern lifestyle }\end{array}$ & \\
\hline
\end{tabular}


In order to achieve the main factors, and therefore the main clustering of customers, in order to identify consumer ethical behavior and thus find appropriate solutions for better and more efficient sales and increase market share, it is necessary to evaluate the factors on the basis of targeted indicators. In this respect, when examining the literature, the following indicators were established for the analysis and evaluation of the key factors.

C 1: Reduction of the costs of attracting new customers

C 2: Reducing the sensitivity of the customer to changes and prices
C 3: Benefits of the value of the life of the customer

C 4: Positive performance by increasing predictive power

C 5: Raise the barriers to entry for potential competitors

It is clear that the above factors are evaluated on the basis of qualitative and verbal values. So, they convert to quantitative variables.

Table 2 summarizes the average opinion of the 15 experts in the table. This decision matrix table poses the question of evaluating and identifying the most relevant variables.

Table 2: Results of Evaluation

\begin{tabular}{|c|c|c|c|c|c|}
\hline Criteria & $\begin{array}{l}\text { C 5: Raise } \\
\text { the barriers } \\
\text { to entry for } \\
\text { potential } \\
\text { competitors }\end{array}$ & $\begin{array}{l}\text { C 4: Positive } \\
\text { performance } \\
\text { by increas- } \\
\text { ing predic- } \\
\text { tive power }\end{array}$ & $\begin{array}{l}\text { C 3: Benefits } \\
\text { of the value } \\
\text { of the life of } \\
\text { the cus- } \\
\text { tomer }\end{array}$ & $\begin{array}{l}\text { C 2: Reducing } \\
\text { the sensitivity of } \\
\text { the customer to } \\
\text { changes and } \\
\text { prices }\end{array}$ & $\begin{array}{l}\text { C1: Reduc- } \\
\text { tion of the } \\
\text { costs of at- } \\
\text { tracting new } \\
\text { customers }\end{array}$ \\
\hline Customer Loyalty & 5.089 & 4.933 & 3.878 & 5.689 & 5.311 \\
\hline Communication factors & 5.933 & 5.656 & 7.333 & 6.833 & 7.044 \\
\hline Customer Relation Management & 5.178 & 5.622 & 3.378 & 5.589 & 4.956 \\
\hline Ethical Behavioral factors & 6.822 & 6.400 & 7.100 & 6.900 & 7.333 \\
\hline Customer Satisfaction & 4.778 & 4.900 & 4.067 & 5.444 & 5.333 \\
\hline Economic Factors & 6.611 & 6.344 & 7.956 & 7.422 & 7.078 \\
\hline Factors affecting the non-purchase of customers & 5.222 & 5.144 & 5.489 & 5.667 & 4.967 \\
\hline Customer Experience Management & 4.889 & 4.700 & 3.767 & 6.100 & 5.233 \\
\hline Individual factors & 6.867 & 6.744 & 7.267 & 6.489 & 7.033 \\
\hline
\end{tabular}

In order to determine the weight and importance of the indicators, the entropy method has been used and the steps taken to implement it have been taken as follows. The normalized decision matrix in the form of Table 3 is obtained by applying the linear norm and using relevant relation. The uncertainty of each indicator, $E \mathrm{j}$, as well as the amount of data scattering by index, $\mathrm{d} j$, are shown in Table 3.

Table 3: Entropy process

\begin{tabular}{|c|c|c|c|c|c|}
\hline & $\begin{array}{l}\text { C 5: Raise the } \\
\text { barriers to en- } \\
\text { try for potential } \\
\text { competitors }\end{array}$ & $\begin{array}{l}\text { C 4: Positive per- } \\
\text { formance by in- } \\
\text { creasing predic- } \\
\text { tive power }\end{array}$ & $\begin{array}{l}\text { C } 3 \text { : Benefits } \\
\text { of the value } \\
\text { of the life of } \\
\text { the customer }\end{array}$ & $\begin{array}{l}\text { C 2: Reduc- } \\
\text { ing the sensi- } \\
\text { tivity of the } \\
\text { customer to } \\
\text { changes and } \\
\text { prices }\end{array}$ & $\begin{array}{l}\text { C1: Reduc- } \\
\text { tion of the } \\
\text { costs of at- } \\
\text { tracting new } \\
\text { customers }\end{array}$ \\
\hline Customer Loyalty & 0.099 & 0.098 & 0.077 & 0.101 & 0.098 \\
\hline Communication factors & 0.115 & 0.112 & 0.146 & 0.122 & 0.130 \\
\hline Customer Relation Management & 0.101 & 0.111 & 0.067 & 0.100 & 0.091 \\
\hline Ethical Behavioral factors & 0.133 & 0.127 & 0.141 & 0.123 & 0.135 \\
\hline Customer Satisfaction & 0.093 & 0.097 & 0.081 & 0.097 & 0.098 \\
\hline Economic Factors & 0.129 & 0.126 & 0.158 & 0.132 & 0.130 \\
\hline
\end{tabular}




\begin{tabular}{|c|c|c|c|c|c|}
\hline $\begin{array}{c}\text { Factors affecting the non-purchase of cus- } \\
\text { tomers }\end{array}$ & 0.102 & 0.102 & 0.109 & 0.101 & 0.091 \\
\hline Customer Experience Management & 0.095 & 0.093 & 0.075 & 0.109 & 0.096 \\
\hline Individual factors & 0.134 & 0.134 & 0.145 & 0.116 & 0.130 \\
\hline $\mathrm{E}_{\mathrm{j}}$ & 0.995 & 0.996 & 0.978 & 0.997 & 0.994 \\
\hline $\mathrm{d}_{\mathrm{j}}$ & 0.005 & 0.004 & 0.022 & 0.003 & 0.006 \\
\hline $\mathrm{w}_{\mathrm{j}}$ & 0.115 & 0.091 & 0.574 & 0.065 & 0.155 \\
\hline
\end{tabular}

It can be seen that the highest distribution is related to the Customer Life Value Benefit Index, and we expect the most weight for this index. The final weight of the indicators is also specified in the last row of Table 3 , and it can be seen that the highest weight and the greatest impact on the assessment and classification of the customer are the 'benefits of the value of the life of the customer. Now, in order to rank and select a set of agreed options and identify the main clusters, the VIKOR method is used.

Table 4: VIKOR index for various value of $\mathrm{v}$

\begin{tabular}{|l|l|l|l|l|l|l|l|l|l|l|l|l|}
\hline & Rank & Mean & $\boldsymbol{v}=\mathbf{1 . 0}$ & $\boldsymbol{v}=\mathbf{0 . 9}$ & $\boldsymbol{v}=\mathbf{0 . 8}$ & $\boldsymbol{v}=\mathbf{0 . 7}$ & $\boldsymbol{v}=\mathbf{0 . 6}$ & $\boldsymbol{v}=\mathbf{0 . 5}$ & $\boldsymbol{v}=\mathbf{0 . 4}$ & $\boldsymbol{v}=\mathbf{0 . 3}$ & $\boldsymbol{v}=\mathbf{0 . 2}$ & $\boldsymbol{v}=\mathbf{0 . 1}$ \\
\hline A1 & 7 & 0.9159 & 0.9394 & 0.9342 & 0.9290 & 0.9238 & 0.9186 & 0.9133 & 0.9081 & 0.9029 & 0.8977 & 0.8925 \\
\hline A2 & 4 & 0.1530 & 0.1897 & 0.1816 & 0.1734 & 0.1653 & 0.1571 & 0.1490 & 0.1408 & 0.1327 & 0.1245 & 0.1164 \\
\hline A3 & 9 & 1 & 1.0000 & 1.0000 & 1.0000 & 1.0000 & 1.0000 & 1.0000 & 1.0000 & 1.0000 & 1.0000 & 1.0000 \\
\hline A4 & 3 & 0.1307 & 0.1061 & 0.1115 & 0.1170 & 0.1225 & 0.1280 & 0.1335 & 0.1389 & 0.1444 & 0.1499 & 0.1554 \\
\hline A5 & 6 & 0.8977 & 0.9412 & 0.9315 & 0.9219 & 0.9122 & 0.9026 & 0.8929 & 0.8833 & 0.8736 & 0.8640 & 0.8543 \\
\hline A6 & 1 & 0 & 0.0000 & 0.0000 & 0.0000 & 0.0000 & 0.0000 & 0.0000 & 0.0000 & 0.0000 & 0.0000 & 0.0000 \\
\hline A7 & 5 & 0.6307 & 0.7180 & 0.6986 & 0.6792 & 0.6598 & 0.6404 & 0.6210 & 0.6016 & 0.5822 & 0.5628 & 0.5435 \\
\hline A8 & 8 & 0.94397 & 0.9699 & 0.9641 & 0.9584 & 0.9526 & 0.9468 & 0.9411 & 0.9353 & 0.9296 & 0.9238 & 0.9181 \\
\hline A9 & 2 & 0.1102 & 0.0997 & 0.1020 & 0.1044 & 0.1067 & 0.1091 & 0.1115 & 0.1138 & 0.1162 & 0.1186 & 0.1209 \\
\hline
\end{tabular}

Table 5: Satisfactory set for various value of $\mathbf{v}$

\begin{tabular}{|c|c|c|c|c|c|c|c|c|c|c|}
\hline various value of $\boldsymbol{v}$ & $\boldsymbol{v}=\mathbf{1 . 0}$ & $\boldsymbol{v}=\mathbf{0 . 9}$ & $\boldsymbol{v}=\mathbf{0 . 8}$ & $\boldsymbol{v}=\mathbf{0 . 7}$ & $\boldsymbol{v}=\mathbf{0 . 6}$ & $\boldsymbol{v}=\mathbf{0 . 5}$ & $\boldsymbol{v}=\mathbf{0 . 4}$ & $\boldsymbol{v}=\mathbf{0 . 3}$ & $\boldsymbol{v}=\mathbf{0 . 2}$ & $\boldsymbol{v}=\mathbf{0 . 1}$ \\
\hline Satisfactory set & $\{\mathrm{A} 6, \mathrm{~A} 9, \mathrm{~A} 4\}$ & $\{\mathrm{A} 6, \mathrm{~A} 9, \mathrm{~A} 4\}$ & $\{\mathrm{A} 6, \mathrm{~A} 9, \mathrm{~A} 4\}$ & $\{\mathrm{A} 6, \mathrm{~A} 9, \mathrm{~A} 4\}$ & $\{\mathrm{A} 6, \mathrm{~A} 9\}$ & $\{\mathrm{A} 6, \mathrm{~A} 9\}$ & $\{\mathrm{A} 6, \mathrm{~A} 9\}$ & $\{\mathrm{A} 6, \mathrm{~A} 9\}$ & $\{\mathrm{A} 6, \mathrm{~A} 9, \mathrm{~A} 2\}$ & $\{\mathrm{A} 6, \mathrm{~A} 2, \mathrm{~A} 9\}$ \\
\hline
\end{tabular}

Table 5 shows that different sets of satisfactory options are identified as superior responses based on the VIKOR method for different values of $\mathrm{v}$. Since there was no priority in this analysis, and according to the managers, to follow a particular strategy for choosing the full weight of group desirability, a total of four factors listed in the accepted sets of Table 5, i.e. A 6: economic factors, A 9: human factors, A 4: ethical behavioral factors
In Table 4, the value of the VIKOR index is determined on the basis of the various values of the agreement parameter $\mathrm{v}$. The reason for this is to select a range of accepted choices and to choose the correct customer cluster. It can be shown that option A 6 was the best option in all values of $\mathrm{v}$. For $\mathrm{v}=0.1$, option A 2 rows second, and for the rest of values $\mathrm{v}$, option $\mathrm{A} 9$ rows second. 
have had its factors. According to experts, customers are divided into four clusters which any person in the first cluster because of communication factors are called "loyal customers". Such customers also attempt to communicate with companies by using the product, the amount of the return, the amount of customer contact, the number of sales and the purchase amount, those people want to have a strategic relationship with businesses, because they rely on Internet of Things technology for their work. In the second cluster, there are customers whose factors have influenced their buying behavior. According to experts, these customers are affected by the nature of services, advice from others, business features, shopping experience, advertisement and service support, and seek to purchase from the services of companies. In the third cluster, which is called individual factors, features such as age, gender, education level and modern lifestyle have played a major role in the purchase of customers, and the results of demographic studies have also shown that all customers have a university education and that's why they've chosen a modern lifestyle, and most men are middle-aged. With regard to the fourth cluster, it can be said that economic factors play an important role in selling services to such customers, including service prices, income levels, employment, sales discounts, credit sales and installment sales. If the above requirements are met, these customers will purchase the services. In this situation, both the main and sub-clusters that were implemented in the marketing model should be considered as methods for sales promotion.

Quantitative section: Furthermore, in order to verify the results obtained from the opinions of the introduced experts, it is necessary to know from the customers ' opinions how much these established factors have influenced their buying behavior, which was given to them in the form of a closed questionnaire. After the data are collected and analyzed, the results are as follows:

Initially, the demographic findings of the clients were examined, and the results showed that 55 of them were female and 329 were male, 211 had a bachelor's degree, 88 had a master's degree, and 85 had a doctorate. Also, 48 of them were between 20 and 30 years old, 197 people between 30 and 40 years old and 139 people over 40 years old, which shows that most of the customers of the companies are men and people with bachelor's degree and between 30 and 40 years old. The descriptive observations of the identified clusters were initially analyzed. The findings indicate that customers with all of the characteristics described gave high scores. According to the Likert range, the scores are above 2.5 , which is higher than the demanded average. In this regard, the average communication factors are 4.22 as the highest score, the average economic factors are 3.77 as the lowest score, the average ethical behavioral factors are 3.98 and the average individual factors is 4.15.

In this portion, the exploratory factor analysis method was used to determine the load factor for each of the main clusters and within the clusters identified, the results of which are as described in Table 6. According to the aforementioned table, all operating loads under clusters are above 0.70 and the average extracted variance is over 0.50. As a consequence, we can see the strong influence of each element on the desired model

Table 6: Exploratory factor analysis

\begin{tabular}{|l|l|l|l|}
\hline Main Clusters & \multicolumn{1}{|l|}{ The load factor } & Sub Clusters & Medium extracted variance \\
\cline { 2 - 3 } Communication factors & 0.783 & Service usage & Revisit rate \\
\cline { 2 - 3 } & 0.791 & $\begin{array}{l}\text { The extent of communica- } \\
\text { tion with the company }\end{array}$ & \multirow{2}{*}{0.673} \\
\cline { 1 - 3 } & 0.811 & Suggestions & \\
\cline { 2 - 3 } & 0.701 & Shopping rate & \multirow{2}{*}{0.655} \\
\cline { 2 - 3 } & 0.743 & Quality & Advise others \\
\hline
\end{tabular}




\begin{tabular}{|c|c|c|c|}
\hline & 0.716 & Service functions & \\
\hline & 0.734 & Shopping experience & \\
\hline & 0.793 & Advertising & \\
\hline & 0.831 & Service support & \\
\hline \multirow[t]{4}{*}{ Individual factors } & 0.740 & age & \multirow{4}{*}{0.690} \\
\hline & 0.794 & $\operatorname{sex}$ & \\
\hline & 0.843 & Level of education & \\
\hline & 0.729 & Modern lifestyle & \\
\hline \multirow[t]{6}{*}{ Economic factors } & 0.732 & Service prices & \multirow{6}{*}{0.761} \\
\hline & 0.766 & Income level & \\
\hline & 0.825 & Job & \\
\hline & 0.866 & Sales discounts & \\
\hline & 0.840 & selling the credit & \\
\hline & 0.748 & leasing & \\
\hline
\end{tabular}

The redundancy index and the coefficient of determination are used to evaluate the quality of the model. Positive numbers respectively 0.711 and 0.790 indicate the appropriate quality of the model. The coefficient of determination shows that $79 \%$ of targeted marketing changes are identified by sub-clusters and the main clusters are predicted. Also, the redundancy index is above zero, so the observed values are well reconstructed and the model is capable of forecasting.
The FORNELL-LARCKER test was used to investigate divergent validity for model dimensions. The findings shows that the structures are completely separate, meaning that the instantaneous drop values for each hidden variable are greater than their dimension of correlation with the other hidden reflective dimensions of the model.

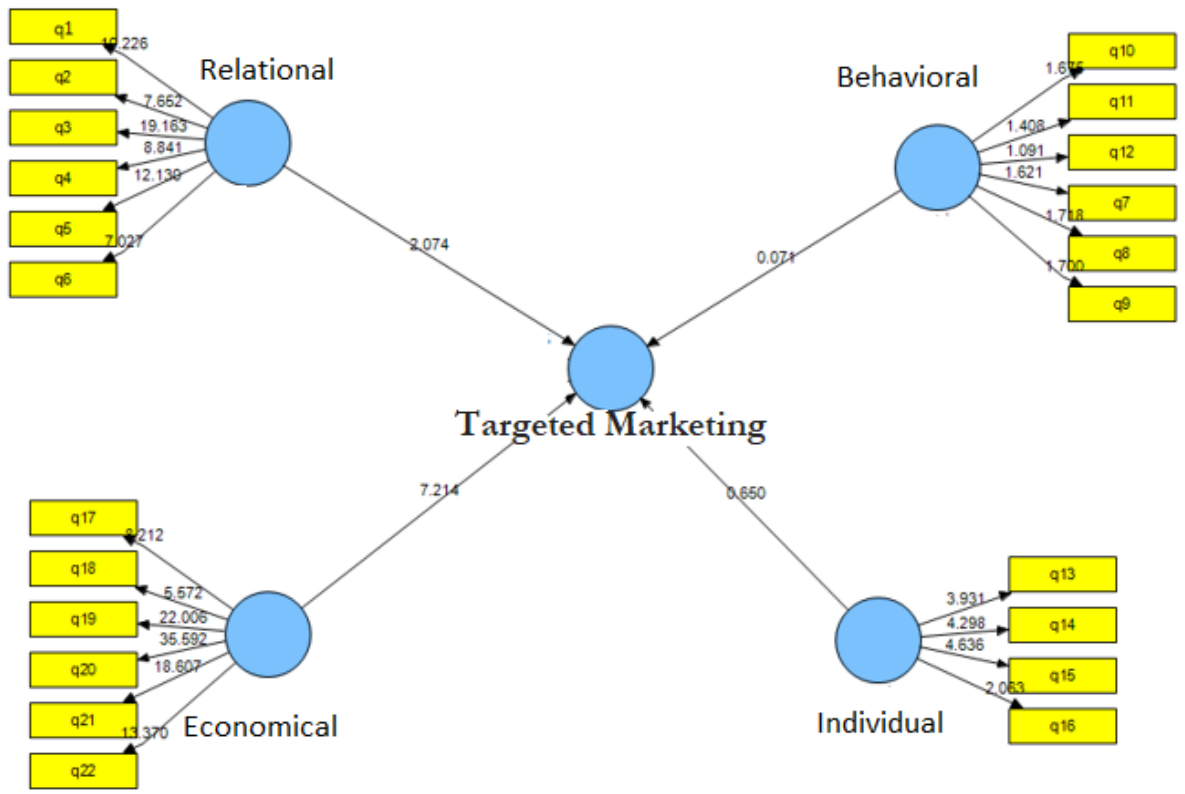

Fig. 1: Ethical Targeted Marketing model in meaningful mode 
In this section, the model will be quantified using a partial square technique and a t-bootstrapping test and the result is shown in figure 1 . The figure shows the model is significant and the findings can be cited.

Table 7: Statistics related to the goodness of model fit

\begin{tabular}{|c|c|c|c|c|}
\hline Fitting Criteria & Symbol & Criterion & Research values & The result of fitting \\
\hline Divide the $\chi$ square by the degree of freedom & X2/df & $\leq 3$ & 1.34 & Good Fitting \\
\hline The root of the mean squared error estimates & RMSEA & $\leq 0.08$ & 0.03 & Good Fitting \\
\hline Good fit index & GFI & $\geq 0.9$ & 0.94 & Good Fitting \\
\hline Adjusted fitness index & AGFI & $\geq 0.9$ & 0.91 & Good Fitting \\
\hline Comparative fit index & CFI & $\geq 0.9$ & 0.93 & Good Fitting \\
\hline Incremental fitness index & IFI & $\geq 0.9$ & 0.92 & Good Fitting \\
\hline Soft fit index & NFI & $\geq 0.9$ & 0.96 & Good Fitting \\
\hline Non-soft fit index & NNFI & $\geq 0.9$ & 0.76 & Good Fitting \\
\hline The coefficient of determination & R2 & $\geq 0.67$ & & G \\
\hline
\end{tabular}

Goodness of fit index including: GFI, AGFI, and RMSEA is used to fit the model. The values obtained in Table 7 indicate that model is reliable and well-suited

\section{Discussion}

The results showed that the model had four main clusters, including: communication factors, ethical behavioral factors, individual factors and economic factors, which customers were categorized in one of these clusters according to their characteristics.

The cluster of connectivity factors has shown that the customers of this cluster are trying to establish a strategic alliance with companies due to the business dependency of these customers on IOT services. These individuals have also made a lot of transactions and are considered to be a kind of strategic and loyal customer of the company. The findings of this cluster are consistent with the results of (11-12), because they have demonstrated that there are customers in companies that have a long-term relationship with industries due to the strategic need for the services or goods of a business. In this respect, it is suggested that managers of IOT technology providers seek to provide the necessary support to these customers in the form of the delivery of relevant facilities and after-sales services in order to maintain them. Such consumers can also be regarded as profitable customers of the company and can be considered the main cluster for the organization.

With respect to the cluster of ethical behavioral variables, it can be said that this cluster of consumers pays a great deal of attention to the quality of services and the behavior of these customers is affected by the advice of others or by the experience of shopping and advertising. The results of this cluster are consistent with the results of the research carried out by (13-14). They found that the quality of service played an important role in the buying behavior of the customer. With regard to these observations, it can be said that, owing to the applicability of services, efficiency is a concern for these consumers, and they pay no to costs and attention it is suggested that the managers of such companies try to determine the amount of quality requested by customers by conducting a survey of this cluster of customers and in a way, defining quality from a customer's point of view, which increases and perpetuates such customers within organizations.

Regarding the cluster of individual factors, it can be said that such customers try to use Internet of Things technologies due to their modern lifestyle and university education, and in fact, most of these customers were men who tend to be using this technology rather than women because of their greater involvement in jobs. The results of this cluster are consistent with the results of (15-16), which showed that lifestyle can stimulate customer 
buying behavior. Using information and communication technology, customers are now turning to the use of such techniques and this has a huge effect on their buying behavior. Therefore, it is recommended that managers of the companies studied try to make this group of customers more loyal by providing luxury services. And, on the other hand, they must employ people who interact with these customers who have a high level of technical knowledge of the company's services, which increases the impact on these customers.

As far as the cluster of economic factors is concerned, it can be said that this cluster of customers often pays attention to the price of services or to the terms of sales that are important to them. The results of this cluster are consistent with the results of the research conducted by (17-18) which found that price and sales could increase the customer's motivation to buy. As far as these results are concerned, it can be said that there are many customers who are trying to buy online services, first want to figure out the price of the services and then buy them, or want to buy them on credit and installments. Therefore, it is suggested that the managers of the surveyed companies try to make less profit in selling services to these customers or, by converting these customers into strategic customers, they can sell the services on installments and credit while receiving the requisite guarantees. At the end, it is worth noting that each study has certain limitations, and the generalization of findings to other companies and the intrinsic limitations of the questionnaire were the most significant limitations of this research. For the future, researchers will also be able to use other approaches, such as system dynamics, modeling and decision-making, to classify consumer clusters.

\section{Conclusion}

The objective of the present study was to highlight the role of customer clustering in the design of an ethical and targeted marketing model. In order to do this, different categories of customers were evaluated in the first phase, with the help of entropy and VIKOR decision-making techniques, and four categories were selected as a consensual response set. These results showed that the model had four main clusters, including: communication factors, ethical behavioral factors, individual factors and economic factors, which customers were categorized in one of these clusters according to their characteristics. In the second phase, the model quantitatively examined and validated and finally approved. The results of the research showed that ethical behavioral factor is one of the four fundamental clusters and the main elements in targeted marketing models for the IOT industry and special attention should be paid to this important item.

\section{Ethical Consideration}

The authors have observed all the ethical points in this article, including informed consent, good behavior, no plagiarism, duplication, data distortion and data generation.

\section{Conflict of Interest}

The authors declare that there is no conflict of interests.

\section{Acknowledgement}

We would like to thank Mr. Qaisari (Internet of Things Research Center) as well as Dr. Ghanbari and Dr. Shirazi. Also, from all those who helped us in this research.

\section{References}

1. Gustriansyah R, Ermatita DR, Malik RF (2020). Integration of decision-making method and data-mining method as a preliminary study of novel sales forecasting method. International Journal of Advanced Trends in Computer Science \& Engineering, 9(4): 5730-5735. Doi: http://dx.doi.org/10.30534/ijatcse/2020/227942020

2. Coluccia D, Dabić M, Del Giudice M, Fontana S, Solimene $S$ (2020). R\&D innovation indicator and its effects on the market. An empirical assessment from a financial perspective. Journal of Business Researh, 119: 259-271. Doi: https:// doi.ong/10.1016/j.jbusres.2019.04.015

3. Lu Z, Peiyi W, Ping C, Xianglong L, Baoqun Z, Longfei M (2019). Customer segmentation algorithm based on 
data mining for electric vehicles. $4^{\text {th }}$ International Conference on Cloud Computing and Big Data Analysis (ICCCBDA), IEEE.

4. Aggarwal AG, Yadav S (2020). Customer segmentation using fuzzy-AHP and RFM model. $8^{\text {th }}$ International Conference on Reliability, Infocom Technologies and Optimization (Trends and Future Directions), Amity University, Noida/India.

5. Esmaeeli M, Hashemi H (2019). Segmentation problem in direct market campaigns: Modified Bat Algorithm. $5^{\text {th }}$ International Conference on Optimization and Applications (ICOA), IEEE.

6. Suhanda R, Fahrullah A (2020). Islamic business ethics on customer retention. International Conference on Research and Academic Community Services, Atlantis Press.

7. Herhausen D, Kleinlercher K, Verhoef PC, Emrich O, Rudolph T (2019). Loyalty formation for different customer joumey segments. J Retailing, 95(3): 9-29. Doi: https://doi.org/10.1016/i.jretai.2019.05.001

8. Lee A (2019). Black hole: A new heuristic optimization approach for data clustering. Information Sciences, 222: 175184. Doi: https://doi.org/10.1016/j.ins.2012.08.023

9. Amiri M, Hadi Nejad F, Malek Khoyan S (2017). Evaluation and prioritization of suppliers with a combined entropy approach, hierarchical analysis process and modified pramity (Case study: Utab Company). Operations Research in Its Applications. 14 (4): 1-20. (In Persian).

10. Rezaei F, Ghaybdoost H (2016). A study of the financial performance of the banking industry using the Vikor method. Quarterly Journal of Development and Transformation Management, (Special issue): 33-43. (In Persian).
11. Ansari A, Riasi A (2016). Customer clustering using a combination of fuzzy $\mathrm{C}$-means and genetic algorithms. International Joumal of Business and Management, 11(7): 59-66

12. Tleis M, Callieris R, Roma R (2017). Segmenting the organic food market in Lebanon: an application of k-means cluster analysis. British Food Joumal, 119(7): 1423-1441. Doi: https://doi.org/10.1108/BFJ-08-2016-0354

13. Hiziroglu A, Senbas UD (2016). An application of fuzzy clustering to customer portfolio analysis in automotive industry. International Journal of Fur:y System Applications (IJFSA), 5(2): 13-25. Doi: http://dx.doi.org/10.4018/IJFSA.2016040102

14. Azadnia AH, Saman MZM, Wong KY, Hemdi AR (2011). Integration model of Fuzzy C means clustering algorithm and TOPSIS method for customer lifetime value assessment. International Conference on Industrial Engineering and Engineering Management, IEEE.

15. Bose I, Chen X (2015). Detecting the migration of mobile service customers using fuzzy clustering. Information \& Management, $\quad 52(2)$ : 227-238. Doi: https://doi.org/10.1016/j.im.2014.11.001

16. Abbas A, Nisar QA, Mahmood MH, Chenini A, Zubair A (2019). The role of Islamic marketing ethics towards customer satisfaction. JIMA, 11(4): 1001-1018. Doi: http://dx.doi.org/10.21043/bisnis.v9i1.10267

17. Fathian M, Azhdari E (2017). Extracting customer behavior pattern in a telecom company using temporal fuzzy clustering and data mining. Journal of Information Technology Management, 9(3): 549-570. Doi: https://dx.doi.org/10.22059/jitm.2017.61437

18. Gholami S, Karimiankakolaki M, Ghobeyshavi H (2015). Developing marketing strategies based on risk management by using Dematel technique. Social Sciences, 4(1). 